\title{
City-regions and city-regionalism
}

\section{Moisio, Sami}

Edward Elgar

2018-07-29

Moisio , S \& Jonas , A E G 2018 , City-regions and city-regionalism . in A Paasi , J Harrison \& M Jones (eds), Handbook on the geographies of regions and territories . , 23 , Research Handbooks in Geography series , Edward Elgar , Cheltenham , pp. 285-297 . https://doi.org/10.4337/978178536580

http://hdl.handle.net/10138/311034

https://doi.org/10.4337/9781785365805.00034

acceptedVersion

Downloaded from Helda, University of Helsinki institutional repository.

This is an electronic reprint of the original article.

This reprint may differ from the original in pagination and typographic detail.

Please cite the original version. 
M oisio, S. \& Jonas, A.E.G. (2018). City-regions and city-regionalism. In Paasi, A. Harrison, J. \& Jones, M. (eds.) Handbook on the Geographies of Regions and Territories. 285-297. Edward Elgar Publishing, Cheltenham.

\section{City-regions and city-regionalism}

Sami Moisio and Andrew E.G. Jonas

\section{Introduction}

Today, the terms city-region and city-regionalism are widely used by urban managers, planners, representatives of businesses associations and international organizations, real estate and property developers and state officials and politicians. These terms are not only catchwords in urban policy practices but also disclose the complex intertwining of contemporary urbanization, world economy and world politics. As such, they reveal much about the diverse ways in which the state and the economy are being spatially reconfigured, and also about the production of new state territorial formations at the city-region scale (Brenner 2004). As Harrison and Hoyler (2015a, p. 2) indicate, there is a great deal of "buzz and appetite" amongst academics as well as state policymakers, consultants and planners about the rise of city regions and, in particular, megaregions (major agglomerations comprised of several metropolitan areas) as the primary sites of economic growth, planning and governance in the contemporary global economy. This new spatial policy imaginary manifests itself in, for instance, recent books suggesting that a world of "connectography" (Khanna 2016) - a world of metropolitan and regional formations - has replaced the world of nation-state territories. This is a new world in which cities and their mayors are supposed to 
be better equipped to solve "global problems" than is the case for the nation state and subnational state governments (Barber 2013).

Following a brief discussion of the global dimensions of city-region growth, we examine a range of academic interpretations of this phenomenon. We suggest that city-regions should not be understood as discrete spatial units that operate as "agents" or "actor-scales" in themselves. Nor should city-regions be considered as passive backdrops on which economy, politics or social reproduction simply happen. Rather city-regions may be conceptualized as dynamic sites of policy experimentation and political struggle, which are produced from various political processes operating within and around the national state and its institutions. Such processes highlight ongoing geopolitical tensions around capital accumulation, which take the form of struggles around social distribution, environment, culture, security, and suchlike. Our emphasis, therefore, is on exposing the geopolitics of city regionalism alongside contingently-manifested problems of social distribution, uneven development, and environmental sustainability; contingencies that nevertheless are important for understanding the social and political construction of city-regionalism in different geopolitical settings.

\section{City-region: the emergence of a concept}

The concept of the city-region first appeared in regional planning in the early twentieth century at a time when the rapid growth of metropolitan-scale urban centres posed a range of new societal challenges relating to housing, social provision, and nationally-balanced economic growth. It is often associated with the writings of influential regional planners and urban reformers, such as Patrick Geddes in the UK and Lewis Mumford in the USA, for 
whom ideas of the "region-city" or "regional city" provided useful devices for discussing and debating the mounting social ills of the industrial city. Later on in the twentieth century, as cities spread further outwards and merged with the surrounding suburbs, villages and rural communities, the "city-region" served both as a planning construct and a statistical unit for measuring and debating urbanization trends in different national settings (Hall, 2009).

In the meantime, statistical definitions of the city-region have evolved along with the size and population of these putative urban-cum-regional agglomerations. Today, urbanization trends are frequently measured at the global scale, being characterized by the explosive growth of city-regions of all sizes. Globally, the UN has estimated that in 2014 there were 28 cityregions with more than 10 million inhabitants, 43 with population between 5 and 10 million, 417 between 1 and 5 million inhabitants, and more than 500 hundred city-regions which fall into a category between 500,000 and 1 million (United Nations 2014). Nevertheless, more than half of the world's urban population live in approximately 2,000 city-regions having less than 500,000 residents (Ibid.).

In the past two decades, urbanization has spread far beyond the political boundaries of the central city and its suburbs, and even those of the sub-state administrative regions and state borders. With regard to the latter case, scholars have identified "megaregions" or "megacityregions" as functional economic entities with the potential to challenge the taken-for-granted power and authority of the nation state. These megacity-regions are manifested as a series of cities that are "functionally networked" and "clustered around one or more larger cities" (Hall and Pain 2006, p. 3). The resultant "stretching" of urbanization has challenged received notions of "the city" conceived in the narrow sense as the most appropriate spatial entity to understand social organization and community stability in the modern era. 
Of course, the "urban" itself is a focus of ongoing theoretical debate in the literature (see Scott and Storper 2015). It therefore would perhaps be foolish to propose a totalizing and universal definition for the concept of the city-region. Indeed, the concept's meaning and usage has shifted throughout the course of the twentieth century. In the 1950s and ' 60 s, the city-region concept was often used in planning and regional science to denote the interaction and division of labour between cities and their surrounding rural areas. One intervention originating around this time in particular stands out from pack. Building on her earlier insights about the importance of the street for urban economic growth (Jacobs 1961), Jane Jacobs subsequently extended her critical gaze to the wider city-region. In Cities and the Wealth of Nations (Jacobs 1984), she argued that the economic success of cities depends on their ability to substitute imports from outside the city region with locally produced commodities; an intervention that has since served as a benchmark for the revival of the cityregion concept in the 1990s and 2000s.

To this day, the city-region concept remains a useful term for describing and measuring different forms of regionalization around central cities. This has involved inter alia measuring the spatial extent of functional city-region interactions (e.g. labour markets, commuting fields, etc.), estimating the economic benefits of spatial agglomeration, or mapping the emergence of new structures of regional collaboration. Indeed, the city-region concept is often to be found in the kitbox of techniques used by professional planners and policy consultants throughout the world. As such, the city-region concept is deployed in multiple city-regional policy imaginaries which are designed to inform and influence public opinion and national policy makers in many different countries. 


\section{City-regions, state territory, and the "global"}

From the vantage point of the present volume, the usefulness of the concept of the city-region further stems from its potential to deconstruct a persistent binary between the external and internal processes of territories, not least those of national state territory. For example, it has appeared as one of the keywords to characterize the replacement of the Fordist and Keynesian national economic and political institutions (Jessop 2000) by conceivably new relational and transnationalizing spatial imaginaries and material structures (Jonas and Ward 2007). These new city-regional territorial structures, in turn, potentially challenge systems of democracy, social reproduction and governance which are premised upon the twentieth-century ideal of the territorially-integrated nation state operating within an inter-state system. In the process, the concept of the city-region has been transformed from a planning category into a powerful theoretical construct, one which has been redesigned better to fit the dynamic processes and patterns of urban development and spatial organization associated with globalization (Rodríguez-Pose 2008). Scott (2001b, p. 813, 817) has expressed the connection between globalization, city-regions and the new world order as follows:

Indeed, as globalization proceeds, an extended archipelago or mosaic of large cityregions is evidently coming into being, and these peculiar agglomerations now increasingly function as the spatial foundations of the new world system that has been taking shape since the end of the 1970s [...] These city-regions form a global mosaic that now seems to be overriding in important ways the spatial structure of coreperiphery relationships that has hitherto characterized much of the macro-geography of capitalist development. 
This process - recently dubbed as "regional urbanization" (Soja 2011) - signals how capital accumulation at the age of globalization takes place around large urban agglomerations rather than nation states having fixed internal and external borders. The implicit message here is that capitalist globalization is to a great extent mediated through the international archipelago of city-regions rather than the system of sovereign territorial states.

It has also become almost axiomatic to argue that the rise of the political-economic significance of city-regions discloses a pivotal moment in the territorial organization and rescaling of the competition state and underpins the neoliberal spatial constitution of globalization more generally (Brenner 2004). However, critiques of this state-theoretical interpretation of the rise of city-regions have suggested that there is nothing inevitably "neoliberal" about the concept and that an interrogation of the processes of city-regionalism can better assist in disclosing progressive politics than somehow representing a neoliberal plot (Harding 2007). In this regard, the literature on state rescaling often fails to disclose the nature of political interests shaping urban development and collective consumption around city-regions (Ward and Jonas 2004). Since factions of capital have different stakes in how city-regions - as well as the spaces within and between them - develop, studying such differences might be crucial for explaining potential conflict and resistance to new territorial structures of the state (Cox 2011).

Scholars have further highlighted the rise of city-regions in a global context. The concept of the global city-region - an interesting spatial marker in itself - does not entail the demise of the territorial state but rather seeks to mark a qualitative shift towards intensive inter-city region interactions, collaboration and rivalries. The literature on global city-regions generally deals with major urban agglomerations - places dominated by some combination of finance 
and producer services, high technology industries, and the creative economy - as key spaces of capital accumulation and within which human capital and productivity increasingly concentrate. Drawing on an earlier work of "world cities" and "global cities", Scott et al. (2001, pp. 11-2) argue that "global city-regions have emerged of late years as a new and critically important kind of geographic and institutional phenomenon on the world stage". Such statements might have prompted somewhat tautological claims to the effect that global city-regions are "global" precisely because they represent highly productive regions which are centred upon "global cities" and contain transnational corporations and other command posts of the world system. Moreover, it is often argued that global city-regions are not only centres of growth, accumulation and innovation but also "liveable" spaces within which enlightened "global" subjects and citizens are made. Notwithstanding the resurgence of nationalism throughout much of the world, it seems that global city-regions are to be viewed as beacons of innovation and progressive politics, which somehow exist in stark contrast to antediluvian or "territorialist" processes seemingly operating elsewhere especially in the socalled “periphery” (see Morgan 2007).

Indeed, an increasing autonomy of political action is one of the defining features of such global city-regions. As such, they are often treated in the literature as spatial exceptions within the national fabric of the state and, as such, function as the (trans)national champions of economic growth, which demand special treatment in respect of state expenditures on research and development, infrastructure and collective social provision. As an outgrowth of pre-existing large metropolitan areas that might have benefitted disproportionately from earlier rounds of state expenditure and prior phases of national economic planning, the rise of global city-regions is not simply a quantitative change in levels of urbanization; instead cityregions need to be understood qualitatively as relational and political constructs, which can 
be identified and delimited not so much by population or geographic size per se as by irreducibly territorial processes. Before we examine such processes, we consider three dominant ways in which city-regions and city-regionalism have been investigated in the literature.

\section{City-regionalism as a societal process}

City-regionalism is, essentially, a socially-mediated process of producing, maintaining and transforming space. In this section, we make a distinction between city-regionalism as, respectively, a set of geo-economic, political-administrative and/or geopolitical processes, which overlap to a greater or lesser degree (Figure 1). As a set of processes, city-regionalism can be comprehended both as a spatial formation which is constituted in and through the dynamics of capital accumulation (or, following Jane Jacobs, the emergent economics of cityregions), and as a particular societal and regulative response to these emergent city-regional economies as well as to the challenges that political communities are more generally perceived to face (i.e., the political-administrative and the geopolitical readings). In the latter meaning, city-regionalism is tied up with the ongoing political struggle and historically contingent forms of capitalist development and associated discursive formations. We begin with briefly reviewing the economic geographical literature on city regionalism, before interrogating city regionalism as a set of political-administrative and/or geopolitical processes in more detail. 


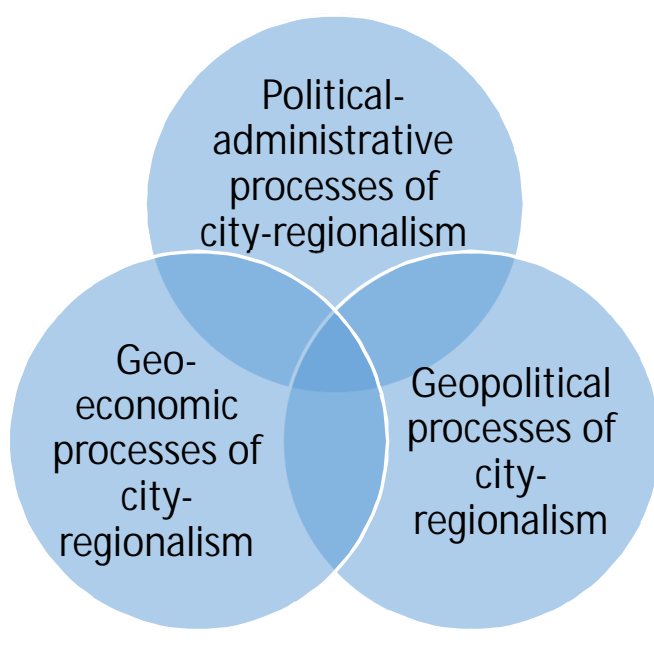

Figure 1. The three dimensions of city-regionalism as a societal process

Geo-economics of city-regionalism

In the work of urban economics, city-regions are often treated as statistical areas which can be compared against each other in order to analyse their differences in, for instance, perworker productivity, and thus assist in mapping the possible operation of agglomeration economies (e.g. Glaeser and Resseger 2010). In such an analysis, "city-regions" are individualized and largely detached from the political and regulatory structures of the state. City-regions emerge around large cities as economically diverse spaces that are well connected and attractive to rationally-behaving workers and employers, who perceive these economic spaces to be ideal locations in their efforts to maximise life chances and business opportunities. Storper (2013) offers an extensive critical review of the neo-classical urban economists' explanations for the rise of city-regions, highlighting the important role played by the co-presence of institutional, social, cultural and, tellingly, political processes. 
The work of urban economists has nonetheless important policy implications. The complementarity between skills and large and dense city-regions, as well as the related link between skills and productivity, has been so widely debated that national governments have faced pressures to tailor policies that would concentrate skills and firms in their most dynamic city-regions (Peirce 1993). The presumed link between metropolitan agglomeration economies and national economic growth plays an increasingly important political function in contemporary state strategies (see, e.g., OECD 2015).

In economic geography, the emergence of the literature on city-regions can be traced back to writings on the rise of a new industrial spaces and a new post-Fordist societal order in the late 1980s and 990s. The emphasis was often placed on the geo-economic resurgence of cityregions. In this literature, city-regions are understood as engines or locomotives of national economies, a sort of intensive economic spaces with dense masses of interconnected economic activities (Scott and Storper 2003). In such a view, city-region is a spatial concentration of economic activities, consumers, firms and services: a sort of functional economic territory which is tightly connected to corresponding territories through the interaction between economic agents.

Economic geographers have been at pains to explain the emergence of city-regions as particular concentrations of economic activities. It is often suggested that the rise of cityregions has to do with the presence of agglomeration economies and associated measures of productivity. Accordingly, city-regionalism signals the intensifying gathering together of many types of productive economic activities ranging from services to manufacturing (Scott 2001b). The Porterian idea of spatial clustering (see, e.g., Porter 2001) - and the related emergence of regional production complexes or urban superclusters which partially stem 
from the need to minimize multifaceted transaction costs in the post-Fordist economy - has been a widely debated factor of city-regional growth. On the other hand, research on the social conventions underpinning regional economic development (Storper 1997) has sought to understand the ways in which the city-regions emerge on the threshold of economy and society. According to the so-called "new regionalism," particular regional worlds of production (city-regions as "regional economies") can be understood as growing out of the technological and organizational worlds that produce regions more generally (Storper 1997, p. 48).

The rise of city-regions and the economic processes of "learning" have also been knitted together. Major city-regions are understood to emerge as concentrations of innovation potentials and skilled work force which dynamic firms are able to harness effectively. Cityregions are thus "learning regions" (see Morgan 1997) which function both as "repositories" and "collectors" of ideas, as well as providing a unique environment which "facilitates the flow of knowledge, ideas and learning" (Florida 1995, p. 527). This dimension of cityregionalism is arguably particularly pertinent in the context of the contemporary "cognitive cultural" economy (Scott 2007) which comprises of high-tech sector, cultural industries and a neo-artisan manufacturing, and which underscores the foundations of localized innovative energy.

City-regionalism and political-administrative processes

The institutions of local government and governance might coincide with the borders of cityregions but often in practice this territorial correspondence between the state and institutionalization around "functional regions" has not been realized. In some national 
contexts, such as in Finland, city-regionalism has emerged as a spatial policy strategy to blur the stark line between cities and their surrounding "rural" areas. The key idea has been to recognize and map "functional regions" (such as labour market areas) and gradually to develop political governance matching the borders of these putative city-regions. Often these new city-regional governance arrangements are designed to be "flexible" and explicitly recognize the importance of the "interstitial" or "soft" spaces existing between formal and functional administrative regions (see Allmendinger and Haughton 2009).

It is very difficult to say to what extent the spatial consequences of material city-regional growth have informed or are impacted by the processes of city-regional governance. What can be said, however, is that bringing together systems of governance and city-regions is often characterized by political struggles and heated contestation. The same applies to the tailoring of city-regional spatial planning systems which would deal with issues such as land use, transportation, housing or economic development. In other words, "functional" cityregions seem to effectively escape and disturb the world of political governance and regulation which is often rooted in historically-construed borders and material interests (in, e.g., land, property or markets) that can have long-lasting impacts on local political institutions and processes (Cox and Jonas 1993).

It is widely assumed that the contemporary political expression of city-regionalism discloses the ways in which capitalism has been territorially re-shaped: the growing importance of cityregions as economic territories and the emergence of metropolitan city-regions as sites of policy experimentation have been closely interconnected processes (Brenner 2004). Yet even a cursory examination of the literature on city-regions suggests that questions of state territoriality and territorial politics generally have been much lower on the research agenda 
than those of economic growth and competitiveness (Cox 2009; Harrison 2007; Jonas 2011). If economic geographers and urban economists have delved insightfully into the constitutive economic processes and features of city-regions, urban political geographers have increasingly sought to trace the political dynamics and regulative structures and institutions of city-regions and city-regionalism. According to such political-geographic interpretations, city-regions are both outcomes and mediums of politics. Attention is now turning to the political construction of city-regions and the ways in which different city-regional formations have been made visible by the state as well as regional and local actors. At the heart of this thematic is the organization and management and governance of city-regions as both as territorializing and de-territorializing spatial units.

In a series of contributions that are indicative of political-geographic investigations of cityregions, John Harrison has sought to unpack the relationship between the territorial politics of city-regionalism and underlying economic and political interests. His research addresses inter alia the relationship between city-region political imaginaries and geographies of investment and uneven development (Harrison 2010; 2014), the degree to which city-regionalism is centrally orchestrated by the state or, conversely, regionally orchestrated by growth coalitions (Harrison 2008), and the manner in which national coalitions representing certain economic sectors have sought to propagate the idea of the megaregion (Harrison and Hoyler 2015a; 2015b). In the latter case, the recent excitement surrounding the megaregion concept in the USA is closely tied to the lobbying activities of the Regional Plan Association of America and the US Department of Transportation, which have used the concept to promote highspeed rail projects (Harrison and Hoyler 2015b) as well as commuter and light rail systems (Jonas et al. 2014). Whilst Harrison (2007) has expressed cautious optimism about the growth 
of serious intellectual interest in city-regions, he nevertheless urges more work on its links to territorial politics (see also Jonas 2012).

Geopolitics of city-regionalism

An inquiry into the political construction of city regions inevitably discloses the contested and often contradictory geopolitical interests and strategies of the national state (Kangas 2013). City-regionalism can hence be further conceptualized as a geopolitical process which brings together the state, city-regions and world politics (Jonas and Moisio 2016).

A geopolitical interpretation of city-regionalism examines the state/city-region interface, and interrogates city-regionalism both as territorializing and de-territorializing spatial strategy. Its emphasis is much more on how city-regions enable the state to project is reach on an international stage than on how city-regions - especially global city-regions - somehow embody or enact processes of economic globalization (Jonas 2013). In such a perspective, city-regionalism is bound to a range of political-economic goals, geopolitical actors and political rationalities, which often make reference to academic constructs. We briefly interrogate some of these themes below.

As noted earlier, city-regionalism is often explained in economic geography and related fields as emanating from economic processes that underpin contemporary capitalist globalization. But theories generated by such academic endeavours can also be understood as forms of constitutive knowledge influencing the policy practices through which city-regionalism is produced. Scientific theories in the field of economic geography are therefore not only explanatory but also prescriptive, and these theories embody substantial policy relevance. As 
we have witnessed since the 1990s, scientific theories on the spatial organization of the "new economy" (how the world is) have also often taken a normative form (concerning how the world should be). Let us take one example which highlights both the economic and political status of city-regionalism in the contemporary political-economic context.

Richard Florida's (2002) theory on the coming together of the creative class and creative economy is undoubtedly one of the most widely circulated and debated theories of urban and regional development in the age of the "knowledge-based economy". This theory is representative of a wider genre of academic writing on the generation of new knowledge and the related human creativity both as key factors of competitive advantage of nations and as inherently spatial-political phenomena (Moisio 2015). Indeed, it can be suggested that both the direct and more implicit politico-spatial implications of the purportedly "knowledge intensive" processes of capitalism form the bedrock of contemporary interest in the geopolitics of city-regionalism. Florida's (2002) much-debated theory of the creative class is thus explicitly located within a purportedly post-industrial world in which creativity and knowledge are replacing the more traditional factors of production.

It is important to note that, along with his subsequent writings (e.g. Florida 2008), Florida's creative class concept celebrates, in effect, the rising importance of city-regions and metropolises. As such, it should also be read as a geopolitical metanarrative of the knowledge-based economy. Specifically, it tells a powerful story about the ways in which capitalism changes and is re-made through economic crises, and how new city-centered political geographies are being produced within the latest ruptures of capitalism. 
One of the key messages of the theory is that following the demise of the previous capitalist era, which was construed around the so-called Keynesian national state, capitalism has remade itself around dynamic cities and larger city-regions. Florida further suggests that in this new geopolitical era city-regions have emergent class qualities which are regarded as crucial for facilitating creativity, innovation and economic growth and, as such, enhance the political and economic development of political communities.

Numerous state and local governments and planning offices have tailored local economic and urban development strategies around selective readings of Florida's theory along with related ideas, such as "creative places" and "smart cities," and a range of consultant companies have put these ideas into motion in different geographical contexts. The widespread adoption of such academic ideas about the rise of city-regions by different state agencies suggest that the production of places - and in particular city-regions - having certain social characteristics is regarded to be a significant factor for the competitive advantage of nations. More generally, therefore, the relationship between city-regions and states has become one of the central dimensions of the contemporary geopolitics of city-regionalism. Many academics have argued that cities and major city-regions increasingly embody significant actorness in world politics and global governance (e.g. Taylor 2011) or that the enhanced political authority of "global city-regions" indicates a weakened sovereign political autonomy of the territorial state (cf. Soja 2011).

Moreover, such ideas about the rising importance of cities and city-regions in the new age of capitalism and its new political condition resonate with a set of other geopolitical writings that were presented in the early 1990s. One of the most telling was produced by Kenichi Ohmae, a Senior Partner of the consultant company McKinsey \& Co and a prolific columnist. 
Ohmae's books and articles in the early 1990s not only mark a notable rupture in writings on the relationship between cities, regions and the nation-state but also embody the new geopolitical context.

Firstly, these writings embody a historically contingent idea that, when compared with "natural" creativity of city-regions, the nation-state is an inherently dysfunctional polity especially in the era of globalizing capitalism. The state should therefore be replaced by new kinds of spatial units: functional and increasingly cross-border economic mega-regions which consist of major urban agglomerations. The megaregion (on this concept, see Harrison and Hoyler 2015b) is a most interesting idea for the study of the geopolitics of city-regionalism. At the heart of this concept is a view of the world according to which significant urban agglomerations are more connected with each other than they are with the people and places in their national backyards (Ohmae 1993; cf. Florida 2008, p. 7).

As first proposed by Ohmae in the early 1990s, the idea that metropolitan regions, not entire nation-states, are the unquestionable hubs of economic growth is part of a wider discursive and material visioning of the de-territorialization of the state and the associated restructuring of world politics that began in the 1980s. Whereas states are dysfunctional entities in spatial terms, major regions become the most effective units in the global economy. These "region states" are more natural business units in part because they have the sufficient, correctly-sized and scaled agglomerations of people and activities for tapping effectively into the global economy (Ohmae 1996): "They are drawn by the deft but invisible hand of the global market for goods and services." (Ohmae 1993, p. 78) 
Secondly, according to the logic above, if the state does not allow its city-regions to enter the global economy, the state as a whole is in danger of becoming a backwater. Ohmae's ideas on the ways in which the central forces of capitalism in the late 1980s began to produce a new region-based geopolitical order proved to be highly influential among consultants, planning gurus and even policy-makers working within state apparatuses. Indeed, it has proven most efficacious in smaller countries lacking in a clearly dominant metropolitan agglomeration; the national governments of such countries have talked up the importance of their largest metropolitan areas as evidence of the need to exploit hitherto untapped assets, including skills, creativity and capital investment, with a view to the nation state itself participating more effectively in the global economy (Jonas and Moisio 2016).

Thirdly, Ohmae's ideas are notable for they opened up a new strand of scholarly writings in future-oriented urban and regional studies. We identify an ideational strand running from his arguments to, for instance, Richard Florida's (1995) treatise on "the learning regions", to Allen Scott's (1996) "regional motors of the global economy" as well as his later contributions on "global city-regions", and to the influential work of Manuel Castells (1996) on the spatial nature of what he conceptualized as the network society.

Nonetheless, addressing the geopolitics of city-regionalism on a more general level touches upon the issue of the internationalization of the state. The geopolitical processes of cityregionalism bring together actors which are often difficult to define on the basis of the received international/national binary. In this capacity, city-regionalism can be understood as an instantiation of state power - a distributed authority which is constituted and re-made by private actors, formal state institutions, international organizations, management consultants, property and real-estate developers, urbanists, lobby organizations, and supranational 
political bodies (cf. Sassen 2008). Accordingly, city-regionalism manifests itself as "partial formations of private and public authority" (Allen and Cochrane 2010, p. 1078) and may well disclose the operation of "transnational state apparatuses" (cf. Demirović 2011, p. 39) as condensation of the relations of political forces that operates on the basis of particular internationalizing transnational priorities in the context of the state, cities and, crucially, capital.

Finally, the geopolitical processes of city-regionalism operate also in a supranational context. To illustrate, the EU's nascent spatial planning system is predicated on an emphasis on market needs, the fundamentals of economic growth, and the idea of enhancing the international competitiveness and attractiveness of the EU as an investment landscape. Furthermore, the system emphasises the role of particular "global economic integration zones" (CEC 1999) as spaces of competitiveness. These demonstrate how just like individual nation states the EU also seeks to "mega-regionalize" itself through a set of cross-border regions that are eventually collections of city-regions. European spatial planning is at least implicitly premised on an idea, which has particular currency in the USA (Wachsmuth 2015), that the megaregion is the most globally effective competitive urban form (Moisio and Luukkonen 2017).

\section{Concluding remarks}

The recent resurgence of the city-region concept clearly captures some significant developments in the spatial patterning of urbanization at the global scale and represents the latest phase in a longer-term trend in the outgrowth of cities into their surrounding areas and political jurisdictions. This trend poses challenges for contemporary regional planning, urban 
policy, and sustainable urban development. It also threatens to undermine the assumed political authority of the nation state. A materialist political economy interpretation highlights how city-regionalism has helped to shed light on broader shifts in the spatial and scalar configuration of capitalism and its supporting systems of societal regulation. Nonetheless, our aim has also been to suggest that city-regionalism often gets constituted as a set of geopolitical processes, which bring together the political and the economic in various state strategies that are instigated by different kinds of political actors (Jonas and Moisio 2016). Increasingly, city-regionalism is politically rationalised through all sorts of conceived challenges, risks and possibilities which touch upon both the security of a particular state and its population. Indeed, whether articulated as a politico-spatial strategy or as a technology of government in these contexts, we suggest that over the course of two decades or more cityregionalism has become one of the key geopolitical processes through which the internationalisation and associated restructuring of the state is envisioned to take place.

From a geopolitical perspective, city-regionalism has major implications not only for the internationalization of the state itself but also how one approaches the internal reconfiguration of state territoriality. City-regionalism is often used to counterbalance uneven regional development and devolutionary tendencies within state territory. Since these political processes of state internationalisation, on the one hand, and internal territorial redistribution, on the other, operate in tension with each other, it is necessary to recognize that the processes of city regionalism remain territorially bounded and that city-regionalism can be rationalised and mobilised through different kinds of geopolitical rationalities. Rather than juxtaposing territorial and relational aspects of city-regionalism in the context of the state, the challenge remains to study the complex coming-together of the relational and the territorial in the processes of city-regionalism. Indeed, the different ways the state and city- 
regions become entangled in efforts to manage the tension between, on the one hand, state's international competitiveness and national redistribution, on the other, remains an interesting research question for spatially-attuned social scientists.

\section{References}

Allen, J. and Cochrane, A. (2010), 'Assemblages of state power: Topological shifts in the organization of government and politics', Antipode, 42, 1071-1089.

Allmendinger, P., and Haughton, G. (2009), 'Soft spaces, fuzzy boundaries, and metagovernance: The new spatial planning in the Thames Gateway', Environment and Planning A, 41 (3), 617-633.

Barber, Benjamin (2013), If Mayors Ruled the World: Dysfunctional Nations, Rising Cities, New Haven: Yale University Press.

Brenner, Neil (2004), New State Spaces: Urban Governance and the Rescaling of Statehood, New York: Oxford University Press.

Castells, Manuel (1996), The Rise of the Network Society, Cambridge, MA: Blackwell.

CEC (1999), 'European spatial development perspective - Towards balanced and sustainable development of the territory of the EU'. Luxembourg: Office for Official Publications of the European Communities.

Cox, K.R. (2009), 'Rescaling the state' in question', Cambridge Journal of Regions, Economy and Society, 2 (1), 107-121.

Cox, K.R. (2011), 'Commentary: from the New Urban Politics to the 'New' Metropolitan Politics', Urban Studies, 48, 2661-2672.

Cox, K.R. and Jonas, A.E.G. (1993), 'Urban development, collective consumption and the politics of metropolitan fragmentation', Political Geography 12 (1), 8-37. 
Demirović, A. (2011), 'Materialist state theory and the transnationalization of the capitalist state', Antipode, 43, 38-59.

Florida, R. (1995), 'Toward the learning region', Futures, 5, 527-536.

Florida, Richard (2002), The Rise of the Creative Class, New York, Basic Books.

Florida, Richard (2008), Who's Your City? How the Creative Economy is Making Where to Live the Most Important Decision of Your Life, New York: Basic Books.

Hall, P. (2009), 'Looking back, looking forward: the city region of the mid-21 ${ }^{\text {st }}$ century', Regional Studies, 43, 803-818.

Hall, Peter and Pain, Kathy (eds.) (2006), The Polycentric Metropolis: Learning from Megacity Regions in Europe, London: Earthscan.

Harding, A. (2007), 'Taking city-regions seriously? Response to debate on 'City-regions: new geographies of governance, democracy and social reproduction', International Journal of Urban and Regional Research, 31, 443-58.

Harrison, J. (2007), 'From competitive regions to competitive city-regions: a new orthodoxy, but some old mistakes', Journal of Economic Geography, 7, 311-332.

Harrison, J. (2008), 'Stating the production of scales: centrally orchestrated regionalism and regionally orchestrated centralism', International Journal of Urban and Regional Research, 32, 922-941.

Harrison, J. (2010), 'Networks of connectivity, territorial fragmentation, uneven development: the new politics of city-regionalism', Political Geography, 29, 17-27.

Harrison, J. (2014), 'Rethinking city-regionalism as the production of new non-state spatial strategies: the case of Peel Holdings Atlantic Gateway Strategy', Urban Studies, 51, $2315-2335$. 
Harrison, John and Hoyler, Michael (2015a), 'Megaregions: foundations, frailties, futures', In John Harrison and Michael Hoyler (eds), Megaregions: Globalization's New Urban Form? Cheltenham: Edward Elgar Publishing, pp. 1-28.

Harrison, John and Hoyler, Michael (eds) (2015b), Megaregions: Globalization's New Urban Form?, Cheltenham: Edward Elgar Publishing.

Glaeser, E. and Resseger, M. (2010), 'The complementarity between cities and skills', Journal of Regional Science, 50, 221-224.

Jacobs, Jane (1961), The Death and Life of Great American Cities, New York: Random House.

Jacobs, Jane (1984), Cities and the Wealth of Nations, New York: Random House.

Jessop, B. (2000), 'The crisis of the national spatio-temporal fix and the tendential egological dominance of globalizing capitalism', International Journal of Urban and Regional Research, 24, 323-360.

Jonas, A.E.G. (2011), 'Region and place: regionalism in question', Progress in Human Geography, 36, 263-272.

Jonas, A.E.G. (2012), 'City-regionalism: questions of distribution and politics', Progress in Human Geography, 36, 822-829.

Jonas, A.E.G. (2013), 'City-regionalism as a contingent 'geopolitics of capitalism', Geopolitics, 18, 284-298.

Jonas, A.E.G. and Moisio, S. (2016), 'City regionalism as geopolitical processes: A new framework for analysis', Progress in Human Geography. Online available at: http://journals.sagepub.com/doi/pdf/10.1177/0309132516679897

Jonas, A.E.G. and Ward, K. (2007), 'Introduction to a debate on city-regions: new geographies of governance, democracy and social reproduction', International Journal of Urban and Regional Research, 31 (1), 169-78. 
Jonas, A.E.G., Goetz, A.R. and Battarcharjee, S. (2014), 'City-regionalism and the politics of collective provision: regional transportation infrastructure in Denver, USA', Urban Studies, 51, 2444-2465.

Kangas, A. (2013), 'Governmentalities of Big Moscow: particularizing neoliberal statecraft', Geopolitics, 18 (2), 299-314.

Khanna, Parag (2016), Connectography. Mapping the Global Network Revolution, London: Weidenfeld \& Nicolson.

Moisio, Sami (2015), 'Geopolitics/critical geopolitics', In John Agnew, Virginie Mamadouh, Anna Secor and Joanne Sharp (eds), The Wiley-Blackwell Companion to Political Geography, Chichester: Wiley-Blackwell, pp. 220-234.

Moisio, Sami and Luukkonen, Juho (2017), 'Notes on spatial transformation in post-Cold War Europe and the territory work of the European Union', In Peter Vihalemm, Anu Masso and Signe Opermann (eds), The Routledge International Handbook of European Social Transformation, Abingdon: Routledge.

Moisio, S. and Paasi, A. (2013), 'From geopolitical to geoeconomic? The changing political rationalities of state space', Geopolitics, 18, 267-283.

Morgan, K. (1997), 'The learning region: Institutions, innovation and regional renewal', Regional Studies, 31 (5), 491-503.

Morgan, K. (2007), 'The polycentric state: new spaces of empowerment and engagement?', Regional Studies, 41 (9), 1237-1252.

OECD (2015), Urban Development. OECD. Last accessed at: http://www.oecd.org/gov/regional-policy/urbandevelopment.htm

Ohmae, K. (1993), 'The rise of the "region state"', Foreign Affairs, 72, 78-87.

Ohmae, Kenichi (1996), The End of the Nation-State: The Rise of Regional Economies, New York: Free Press. 
Peirce, Neal R. (1993), Citistates: How Urban American Can Prosper in a Competitive World, Washington DC: Seven Locks Press.

Porter, Michael (2001), 'Regions and the new economics of competition, In Allen J. Scott (ed), Global City-Regions: Trends, Theory, Policy, Oxford: Oxford University Press, pp. 139-157.

Rodríguez-Pose, A. (2008), 'The rise of the "city-region" concept and its development policy implications', European Planning Studies, 16, 1025-1046.

Sassen, Saskia (2008), Territory, Authority, Rights: From Medieval to Global Assemblages, Princeton NJ: Princeton University Press.

Scott, Allen J. (ed) (2001a), Global City-Regions: Trends, Theory, Policy, Oxford: Oxford University Press.

Scott, A.J. (2001b), 'Globalisation and the rise of city-regions' European Planning Studies, 9, 813-824.

Scott, Allen J., Agnew, John A., Soja, Edward and Storper, Michael (2001), 'Global cityregions', In Allen J. Scott (ed), Global City-Regions: Trends, Theory, Policy. Oxford: Oxford University Press, pp. 11-32.

Scott, A. and Storper, M. (2003), 'Regions, globalization, development', Regional Studies, 37, 579-593.

Scott, A.J. and Storper, M. (2015), 'The nature of cities: the scope and limits of urban theory', International Journal of Urban and Regional Research, 39, 1-15.

Soja, Edward (2011), 'Regional urbanization and the end of the metropolis era', In Gary Bridge and Sophie Watson (eds), The New Blackwell Companion to the City. Oxford: Wiley-Blackwell, 679-89.

Storper, Michael (1997), The Regional World: Territorial Development in a Global Economy, New York: Guilford Press. 
Storper, Michael (2013), Keys to the City, Princeton: Princeton University Press.

Taylor, Peter J. (2011), 'World city networks: Measurement, social organization, global governance, and structural change', In Mark Amen, Noah Toly, Patricia McCarney and Klaus Segbers (eds), Cities and Global Governance, Farnham: Ashgate, pp. 201216.

United Nations (2014), World Urbanization prospects: The 2014 Revision, Highlights. UN Department of Economic and Social Affairs, Population Division. Available at: https://esa.un.org/unpd/wup/publications/files/wup2014-highlights.Pdf

Wachsmuth, David (2015), 'Megaregions and the urban question: the new strategic terrain for US urban competitiveness', In John Harrison and Michael Hoyler (eds), Megaregions: Globalization's New Urban Form?, Cheltenham: Edward Elgar Publishing, pp. 51-74.

Ward, K. and Jonas, A.E.G. (2004), 'Competitive city-regionalism as a politics of space: a critical reinterpretation of the new regionalism', Environment and Planning A, 36, 2112-2139. 